\title{
Water Soluble Aluminum Paste Using Polyvinyl Alcohol for Silicon Solar Cells
}

\author{
Abdullah Uzum, ${ }^{1}$ Taiki Ashikaga, ${ }^{1}$ Takuma Noguchi, ${ }^{1}$ \\ Hiroyuki Kanda, ${ }^{1}$ Toshifumi Matsuoka, ${ }^{2}$ Toru Nakanishi, ${ }^{3}$ Hidehito Fukui, ${ }^{4}$ \\ Tomitaro Harada, ${ }^{4}$ and Seigo Ito ${ }^{1}$ \\ ${ }^{1}$ Department of Electric Engineering and Computer Sciences, Graduate School of Engineering, University of Hyogo, \\ Shosha 2167, Himeji, Hyogo 671-2280, Japan \\ ${ }^{2}$ JAPAN VAM \& POVAL Co. Ltd., Chikukou Shinmachi 3-11-1, Nishiku, Sakai, Osaka 592-8331, Japan \\ ${ }^{3}$ Shin-Etsu Chemical Co. Ltd., Ohtemachi 2-6-1, Chiyoda-ku, Tokyo 100-0004, Japan \\ ${ }^{4}$ Daiwa Sangyo Co. Ltd., 3-4-11 Nakayasui, Sakai, Osaka 590-0063, Japan \\ Correspondence should be addressed to Seigo Ito; itou@eng.u-hyogo.ac.jp
}

Received 12 November 2014; Revised 16 January 2015; Accepted 19 January 2015

Academic Editor: Vincenzo Augugliaro

Copyright (C) 2015 Abdullah Uzum et al. This is an open access article distributed under the Creative Commons Attribution License, which permits unrestricted use, distribution, and reproduction in any medium, provided the original work is properly cited.

Screen-printing aluminum is still dominantly used in the solar cell fabrication process. Ethyl cellulose is one of the main contents of screen-printing pastes that require dichloromethane for its cleaning process, a substance renowned for being extremely toxic and threatening to the human body. Developing environmental friendly aluminum pastes is essential in order to provide an alternative to the commercial pastes. In this work, new, nontoxic polyvinyl alcohol-based aluminum pastes are introduced. Polyvinyl alcohol was used as a soluble polymer that can be synthesized without saponification and that is also soluble in water. Three different pastes were developed using different recipes including many aluminum particle sizes varying from 3.0 to $45 \mu \mathrm{m}$, aluminum oxide with particle sizes between 35 and $50 \mu \mathrm{m}$, and acetic acid. Evaluation of the pastes was carried out by Scanning Electron Microscope (SEM) image analysis, sheet resistance measurements, and fabricating silicon solar cells using each paste. Solar cells with $15.6 \%$ efficiency were fabricated by nonvacuum processing on CZ-Si p-type wafers using developed aluminum pastes on the back side.

\section{Introduction}

Low-cost and high throughput screen-printable materials are widely used in the solar cell fabrication process, especially for metallization purposes. Screen-printing aluminum is still typically utilized in the solar cell fabrication process as a back contact and to form $\mathrm{p}^{+}$aluminum-silicon alloyed back surface fields (BSF) for p-type solar cells or aluminum doped $\mathrm{p}^{+}$rear emitters for $\mathrm{n}$-type solar cells based on the alloying process $[1,2]$. The back surface field is an important phenomenon for p-type crystalline silicon solar cell technology which reduces the back-surface recombination of minority carriers and enhances efficiency [3]. Impurities in the silicon bulk could also be gettered into the aluminum layer, resulting in an improvement in bulk quality. However, the production of aluminum pastes is not so simple and has some drawbacks, including the use of toxic materials. Typically an aluminum paste contains aluminum powder, glass frits, and binder resins [4].

Conventionally, ethyl cellulose is used for polymers as a binder resin for screen-printability and sodium hydroxide is used as a synthesis process in the "saponification" used to attain ethyl cellulose synthesis [5]. For the process of silicon semiconductor, the sodium hydroxide should be removed, because the sodium hydroxide can be a strong contamination to deteriorate the photovoltaic characteristics of silicon semiconductor.

In order to manage ethyl cellulose in the industrial setup, moreover, dichloromethane has been utilized for the removal and cleaning and has harmed human being by induction of bile duct cancer [6]. Ethyl cellulose can be dissolved into nontoxic ethanol also, but the dissolution takes a very long 


\begin{tabular}{|c|c|c|}
\hline Paste 1 & Paste 2 & Paste 3 \\
\hline $\mathrm{Al}$ powder [\#800F, $20 \mathrm{~g}, d=3.0-3.6 \mu \mathrm{m}]$ & $\begin{array}{c}\text { Al powder [\#800F, } 16 \mathrm{~g}, d=3.0-3.6 \mu \mathrm{m}]+ \\
\mathrm{Al} \text { powder }[2 \mathrm{~g}, d=45 \mu \mathrm{m}]+ \\
\mathrm{Al}_{2} \mathrm{O}_{3} \text { powder }[2 \mathrm{~g}]\end{array}$ & $\begin{array}{c}\text { Al powder [\#800F, } 16 \mathrm{~g}, d=3.0-3.6 \mu \mathrm{m}]+ \\
\mathrm{Al} \text { powder }[2 \mathrm{~g}, d=45 \mu \mathrm{m}]+ \\
\mathrm{Al}_{2} \mathrm{O}_{3} \text { powder }[2 \mathrm{~g}]\end{array}$ \\
\hline$\square$ & $\square$ & $\square$ \\
\hline \multicolumn{2}{|c|}{ Add water $(1 \mathrm{~mL})$ and grind in a mortar $(1 \mathrm{~min}) \times 10$ times } & \multirow{2}{*}{ Add acetic acid (2g) } \\
\hline \multicolumn{2}{|c|}{ Adding ethanol $(1 \mathrm{~mL})$ and grinding in a mortar $(1 \mathrm{~min}) \times 3$ times } & \\
\hline \multicolumn{3}{|c|}{ Add ethanol $(100 \mathrm{~mL})$} \\
\hline $\multicolumn{3}{|c|}{$ Stir with a magnet tip $(1 \mathrm{~min})$, sonication with ultrasonic homogenizer $[(2 \mathrm{~s}$ work $+2 \mathrm{~s}$ rest $) \times 30$ times $]} \times 3$ times \\
\hline \multicolumn{3}{|c|}{ Add PVA $(2 \mathrm{~g})$ dissolved in glycerin $(20 \mathrm{~g})$} \\
\hline $\multicolumn{3}{|c|}{$ Stir with a magnet tip $(1 \mathrm{~min})$, sonication with ultrasonic homogenizer $[(2 \mathrm{~s}$ work $+2 \mathrm{~s}$ rest $) \times 30$ times $]} \times 3$ times \\
\hline \multicolumn{3}{|c|}{ Evaporation of water with a rotary evaporator $\left(40^{\circ} \mathrm{C}, 6\right.$ hours $)$} \\
\hline
\end{tabular}

FIGURE 1: Flow chart of polyvinyl alcohol-based aluminum paste production.

TABle 1: Dependence of sheet resistance on the size of Al particles in "Paste 1."

\begin{tabular}{lc}
\hline Al particle size & Sheet resistance $(\Omega / \mathrm{sq})$ \\
\hline$\# 500 \mathrm{~F}(8.0-10.0 \mu \mathrm{m})$ & 0.54 \\
$\# 600 \mathrm{~F}(5.0-6.0 \mu \mathrm{m})$ & 0.051 \\
$\# 700 \mathrm{~F}(4.0-4.6 \mu \mathrm{m})$ & 0.068 \\
$\# 800 \mathrm{~F}(3.0-3.6 \mu \mathrm{m})$ & 0.045 \\
\hline
\end{tabular}

time (sometimes it can be over night). Therefore, developing aluminum pastes using environmentally friendly materials is necessary and should be introduced to the solar cell industry.

As the alternative candidate to eliminate ethyl cellulose, polyvinyl alcohol (PVA) is a nontoxic, less contaminating, and water-soluble polymer that can be synthesized without the $\mathrm{NaOH}$-associated saponification. In this work, we aimed to show that polyvinyl alcohol can be used as a soluble polymer for producing aluminum pastes and that these PVAbased aluminum pastes can be a promising alternative to the commercially used aluminum pastes with ethyl cellulose. We have developed three different screen-printable aluminum pastes with PVA. Preparation of the pastes was explained in detail, and then the applicability of the pastes was investigated in terms of the quality of back surface field layers. Finally, silicon solar cells using these developed pastes were fabricated using nonvacuum processing.

\section{Experimental}

2.1. Preparation of Aluminum Pastes. Three different aluminum pastes were subsequently developed. Aluminum powders with various sizes of aluminum particles were utilized. Aluminum powder with a particle size of $45 \mu \mathrm{m}$ (purchased from Kanto Chemical) or 3.0 to $10.0 \mu \mathrm{m}$ (\#500F, $\# 600 \mathrm{~F}, \# 700 \mathrm{~F}$, and \#800F, purchased from Minalco, shown in Table 1), aluminum oxide with particle sizes ranging from 35 to $50 \mu \mathrm{m}$ (Kanto Chemical), and acetic acid (>99.7\%, Kanto Chemical) were used as the main variable contents.
Polyvinyl alcohol (PVA; PXP-05, saponification ratio: 87$89 \%$, Na amount $<1 \mathrm{ppm}$ ) was provided by JAPAN VAM \& POVAL Co. Ltd.

The aluminum particle with $45 \mu \mathrm{m}$ diameter was used for Paste 2 and Paste 3, not for Paste 1. In order to optimize the small size aluminum particles (<10 microns), Paste 1 was prepared without aluminum powder with excessive size $(45 \mu \mathrm{m})$. After the optimization of small aluminum particles $(3.0-10.0 \mu \mathrm{m})$, aluminum pastes (Paste 2 and Paste 3$)$ were prepared with aluminum powder with excessive size $(45 \mu \mathrm{m})$.

The preparation method for aluminum paste followed essentially the same method as that for $\mathrm{TiO}_{2}$ paste [7]. A detailed flow chart of the production method for each aluminum paste is shown in Figure 1. At first, the main aluminum sources were prepared: aluminum powder (16 g, $d$ $=3.0-3.6 \mu \mathrm{m}, \# 800 \mathrm{~F})$ for Paste 1 , aluminum powder $(\# 800 \mathrm{~F}$, $16 \mathrm{~g}, d=3.0-3.6 \mu \mathrm{m})$, another aluminum powder $(2 \mathrm{~g}, d=$ $45 \mu \mathrm{m})$, and aluminum oxide powder ( $2 \mathrm{~g}$ ) for Paste 2 and for Paste 3, respectively. The aluminum sources for Paste 1 and Paste 2 were added in $1 \mathrm{~mL}$ water and mixed in a mortar for $1 \mathrm{~min}$ (this step was repeated for 10 cycles). After that, $1 \mathrm{~mL}$ ethanol was added and mixed for $1 \mathrm{~min}$ (this step was repeated for 3 cycles). The aluminum source for Paste 3 was only mixed with $2 \mathrm{~g}$ of acetic acid. After the preparations of mortars for each paste, $100 \mathrm{~mL}$ of ethanol was added into the mix mortars, transferred into a glass beaker, and mixed further with a magnetic stirrer for $1 \mathrm{~min}$. Sonication with an ultrasonic homogenizer was applied in cycles of $\langle 2 \mathrm{sec}$ work $/ 2 \mathrm{sec}$ rest $\rangle$. The steps of stirring with magnetic tip and sonication with ultrasonic homogenizer were repeated 3 times. Then, $2 \mathrm{~g}$ polyvinyl alcohol (PVA) dissolved in 20 g glycerin was added to the mixed mortar. Again, the stirring and sonication steps (mixing with a magnetic tip for $1 \mathrm{~min}$ and sonication with ultrasonic homogenizer $[(2 \mathrm{sec}$ work $+2 \mathrm{sec}$ rest $) \times 30$ times $])$ were repeated for 3 times. Finally, water into the mixture was evaporated using a rotary evaporator (bath temperature of $40^{\circ} \mathrm{C}$, for 6 hours) and aluminum pastes were achieved. The amounts of resulting inorganic materials (aluminum and alumina) of Pastes 1, 2, and 3 were 45.8, 46.4, and 
$44.2 \mathrm{wt} \%$, which were measured by thermos gravity analysis, respectively.

2.2. Fabrication of Silicon Solar Cells. CZ-Si p-type wafers with size of $25 \mathrm{~mm} \times 25 \mathrm{~mm}$ (thickness: $500 \mu \mathrm{m}$; resistivity: $5 \Omega \cdot \mathrm{cm}$ ) were used in experiments to fabricate silicon solar cells. At first, for the saw damage etching, all wafers were etched in acidic solution containing $\mathrm{HF}: \mathrm{HNO}_{3}(1: 5$ in volume). For the back side protection from texture etching and phosphorous diffusion, a $\mathrm{SiO}_{2}$ layer was coated at each time before hand. After alkaline texturing, cleaning process \#1 from Radio Corporation of America (RCA-1) by $\mathrm{NH}_{4} \mathrm{OH}: \mathrm{H}_{2} \mathrm{O}_{2}: \mathrm{H}_{2} \mathrm{O}(1: 1: 5$ in volume) and cleaning process \#2 from Radio Corporation of America (RCA-2) by $\mathrm{HCl}: \mathrm{H}_{2} \mathrm{O}_{2}: \mathrm{H}_{2} \mathrm{O}(1: 1: 5$ in volume) were performed to remove organic/inorganic contaminations $[8,9]$. The $\mathrm{POCl}_{3}$ diffusion was performed to form $\mathrm{n}^{+}$emitter. After removal of front phosphate-silica glass and back $\mathrm{SiO}_{2}$ layer by soaking in $10 \% \mathrm{HF}$ aqueous solution, antireflection coating (ARC) of $\mathrm{TiO}_{2}$ was coated by spray pyrolysis deposition on $\mathrm{n}^{+}$ emitter [10]. At last, the PVA-based aluminum pastes and a commercially available aluminum paste were coated by screen printing on the back side of the wafers. Our PVAaluminum pastes were dried at $310^{\circ} \mathrm{C}$ for $30 \mathrm{~min}$ while the commercially available aluminum paste was dried at $125^{\circ} \mathrm{C}$ for $5 \mathrm{~min}$. A commercially available silver paste was printed on the front size of the wafers and dried at $125^{\circ} \mathrm{C}$ for $5 \mathrm{~min}$. Screen-printing was carried out using manually controlled screen-printing tool. For the printing, paste was expanded on the mask and printing was carried out by manually pressuring the rubber squeegee while sliding it on the mask. Cofiring was performed by rapid thermal annealing (RTA). Finally, each edge of wafer was cut with $2.5 \mathrm{~mm}$ width for the edge isolation. The resulting size of the samples used for photocurrentvoltage $(I-V)$ measurements was $20 \mathrm{~mm} \times 20 \mathrm{~mm}$. An AM 1.5 solar simulator (with a $500 \mathrm{~W}$ Xe lamp, YSS-80A, Yamashita Denso, Japan) calibrated to $100 \mathrm{~mW} \mathrm{~cm}^{-2}$ using a reference Si photodiode (Bunkou Keiki, Japan) was employed for photovoltaic measurements. $I-V$ curves were obtained by applying an external bias to the cell and measurement of the generated photocurrent with a DC voltage current source (B2901A, Agilent).

For the SEM image analysis and electrical analysis parts of this work, developed pastes were fully printed on the surface of the silicon wafers of some samples. Firing was carried out at $770^{\circ} \mathrm{C}$ for $1 \mathrm{~min}$. Four-point-probe measurements (LorestaEP MCP-T360, Mitsubishi Chemical Co. Ltd., Japan) were performed to estimate the sheet resistances. The microstructure aluminum pastes and BSF layers were observed through SEM image analysis (JSM-6510, JEOL, Japan).

\section{Results and Discussion}

3.1. Evaluation of the Developed Aluminum Pastes. At first, in order to investigate the optimum aluminum particle size for the paste and the optimum amount of aluminum powder to put into the paste, Paste 1 was developed with various particle sizes of between $3.0-3.6 \mu \mathrm{m}$ (\#800F), 4.0-4.6 $\mu \mathrm{m}$ (\#700F),
TABLE 2: Dependence of the sheet resistance on the amount of $\mathrm{Al}$ used in "Paste 1."

\begin{tabular}{lc}
\hline Amount of $\mathrm{Al}$ powder $(\mathrm{g})$ & Sheet resistance $(\Omega / \mathrm{sq})$ \\
\hline 4 & 154 \\
8 & 150 \\
16 & 0.17 \\
20 & 0.10 \\
32 & 0.10 \\
40 & Not printable \\
\hline
\end{tabular}

TABLE 3: Optimization of PVA-glycerin mix ratio in "Paste 1."

\begin{tabular}{lc}
\hline Amount of glycerin in 2 g PVA & Result \\
\hline $10 \mathrm{~g}$ & Solid \\
$20 \mathrm{~g}$ & Fluid \\
$30 \mathrm{~g}$ & Fluid, low viscosity \\
\hline
\end{tabular}

5.0-6.0 $\mu \mathrm{m}$ (\#600F), and 8.0-10.0 $\mu \mathrm{m}$ (\#500F). Table 1 shows the dependence of the sheet resistivity of aluminum contacts on the aluminum particle size. After full area screen printing of the pastes on the silicon substrate and firing at $770^{\circ} \mathrm{C}$, samples were electrically characterized in terms of sheet resistivity using a four-point-probe method. Sheet resistivity of the aluminum layer formed by the paste with $8.0-10.0 \mu \mathrm{m}$ sized aluminum particles was measured as $0.54 \Omega / \mathrm{sq}$ and decreased significantly to levels lower than $0.07 \Omega /$ sq with $\# 700 \mathrm{~F} \mathrm{Al}$ powder and reaches down to $0.045 \Omega / \mathrm{sq}$ with $\# 800 \mathrm{~F}$ Al powder and provides good conductivity when the paste with aluminum size of 3.0-3.6 $\mu \mathrm{m}$ (\#800F) was applied. Decreasing the particle size can enhance the contacting area between the aluminum particles, which leads to the good conductivity of printed aluminum layer.

The amount of the aluminum powder in "Paste 1" was also optimized (from 4 to $40 \mathrm{~g}$ ). Measured sheet resistivity was given in Table 2 . When the amount of powder was adjusted to $8 \mathrm{~g}$ or less, measured sheet resistivity was around $150 \Omega / \mathrm{sq}$. Sheet resistance decreased significantly by increasing the amount of aluminum powder in the paste. $0.17,0.1$, and $0.1 \Omega /$ sq were achieved when using aluminum powder with an amount of $16 \mathrm{~g}, 20 \mathrm{~g}$, and $32 \mathrm{~g}$, respectively. The aluminum paste became so hard that it could not be printed anymore when the amount of powder was increased up to $40 \mathrm{~g}$ or more. Hence, the amount of aluminum powder (and $\mathrm{Al}_{2} \mathrm{O}_{3}$ powder) was set to be $20 \mathrm{~g}$ for the experiment below.

Optimization of the mixing ratio of PVA and glycerin was carried out with fixation of the PVA amount at $2 \mathrm{~g}$. A summary of the optimization was given in Table 3. Amount of glycerin was varied and the physical condition was observed in order to confirm the viscosity for the utilization to be aluminum pastes. Mixing up to around $10 \mathrm{~g}$ of glycerin with $2 \mathrm{~g}$ PVA became a solid-like mixture which was unsuitable for grinding with any material. When the amount of glycerin was $30 \mathrm{~g}$, the mixture became too liquid to be printed well anymore. Thus the PVA-glycerin mixture used in this work was set to $20 \mathrm{~g}$ of glycerin in $2 \mathrm{~g}$ of PVA for a quality printing. 


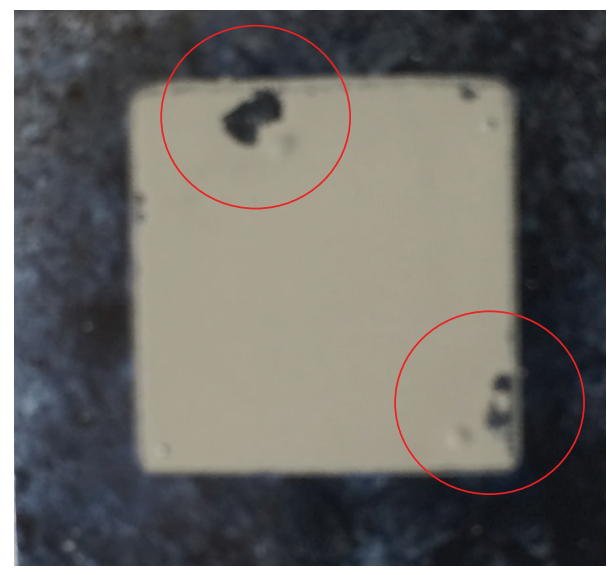

FIGURE 2: Postannealing condition of Paste 1 where detaching of the paste was observed as circled in red.

After the optimization of the main mixtures, the pastes were printed for evaluation. For screen-printing metallization paste, uniform printing and good adherence to the silicon are very important. The postfiring condition of the silicon solar cell with screen-printing metallization using Paste 1 is shown in Figure 2. The detaching of Paste 1 was observed after the firing step and the electrical properties of solar cells fabricated using Paste 1 were found to be not reproducible due to its poor adherence to the silicon wafer. This issue could be avoided by adding aluminum oxide particles into the paste, and poor adherence was not observed for Paste 2 and Paste 3.

Paste 2 is a version of Paste 1 improved by adding largersize aluminum particles and aluminum oxide particles into the paste. SEM images of the aluminum-silicon interface after firing at $770^{\circ} \mathrm{C}$ can be seen in Figures 3(a), 3(b), and 3(c), for Paste 1, Paste 2, and Paste 3, respectively. In order to observe the back surface field layer better, etching with an acidic solution containing $\mathrm{HF}: \mathrm{HNO}_{3}: \mathrm{CH}_{3} \mathrm{COOH}=1: 3: 8$ (ratio in volume: called "Dash etching") was applied for $1 \mathrm{~min}$ after cutting the wafers. SEM images of the aluminum-silicon interface after the acidic etching of the wafers with back surface fields formed using Paste 1, Paste 2, and Paste 3 are shown in Figures 3(d), 3(e), and 3(f), respectively. A back surface field with an average thickness of around $5 \mu \mathrm{m}$ can be confirmed when applying Paste 1 (Figure 3(d)) which is not uniform and has poor adherence to the silicon. In Figure 3(e), poor alloying of Paste 2 with silicon can be observed although Paste 2 interacts better with silicon and shows better adherence than that of Paste 1. In order to improve alloying performance further and to build good adherence between aluminum and silicon at the same time, Paste 2 was improved by adding acetic acid which led us to Paste 3 . In Figure 3(f), good alloying of Paste 3 with silicon can be seen where the back surface field is also considerably uniform and has an average thickness of around $6 \mu \mathrm{m}$. According to the SEM images, better alloying of aluminum with silicon was confirmed with Paste 3 which contains both aluminum oxide and acetic acid in addition to aluminum particles with small $(3.0-3.6 \mu \mathrm{m})$ and large $(45 \mu \mathrm{m})$ diameters.
TABLE 4: Electrical properties of fabricated cells with developed polyvinyl alcohol-based aluminum pastes (average of 3 nontextured, w/o ARC cells).

\begin{tabular}{lccccc}
\hline Paste & & $J_{\mathrm{sc}}\left[\mathrm{mA} / \mathrm{cm}^{2}\right]$ & $V_{\mathrm{oc}}[\mathrm{mV}]$ & $\mathrm{FF}[\%]$ & $\eta[\%]$ \\
\hline \multirow{2}{*}{ Paste 1 } & Average & 31.94 & 551 & 56.0 & 11.14 \\
& $\pm(\%)$ & 1.3 & 4.0 & 0.4 & 0.32 \\
\hline \multirow{2}{*}{ Paste 2 } & Average & 33.74 & 558 & 66.5 & 12.19 \\
& $\pm(\%)$ & 0.9 & 3.0 & 2.2 & 0.14 \\
\hline \multirow{2}{*}{ Paste 3 } & Average & 34.70 & 549 & 69.9 & 13.31 \\
& $\pm(\%)$ & 0.4 & 3.0 & 0.7 & 0.20 \\
\hline
\end{tabular}

The reason of better alloying by Paste 3 would be the reaction of PVA with acetic acid. Actually, the PVA in our paper contains pendant groups of R-OH and $\mathrm{R}-\mathrm{O}-\mathrm{COCH}_{3}$ to control the solubility and viscosity. The remaining $\mathrm{R}-\mathrm{OH}$ group can react as

$$
\mathrm{R}-\mathrm{OH}+\mathrm{CH}_{3} \mathrm{COOH} \longrightarrow \mathrm{R}-\mathrm{O}-\mathrm{COCH}_{3}+\mathrm{H}_{2} \mathrm{O}
$$

This reaction may occur by heating at $100-300^{\circ} \mathrm{C}$. The $\mathrm{R}-\mathrm{OH}$ group can connect the polymer to the surfaces of aluminum and silicon. Hence, the diminishing of $\mathrm{R}-\mathrm{OH}$ can separate PVA polymer from the surfaces of aluminum particles and silicon. The separation between PVA and surfaces of aluminum and silicon after heating would enhance the alloying between aluminum and silicon to be the better BSF for solar cells.

\subsection{Silicon Solar Cells Using Developed PVA-Based Aluminum} Pastes. At first, p-type solar cells were fabricated on nontextured CZ-Si wafers without any ARC in order to compare the photovoltaic results under highly reproducible conditions. Developed PVA-based aluminum pastes were utilized on rear sides where the front contacts were commercially available silver. Electrical characteristics of fabricated cells were summarized in Table 4.

The current density $\left(J_{\mathrm{sc}}\right)$ of $31.94 \mathrm{~mA} / \mathrm{cm}^{2}$ and fill factor of 0.560 were achieved when Paste 1 was used for the aluminum metallization. Compared to solar cells with aluminum back surface fields formed by Paste 1 and Paste 2, the fill factor of the solar cell with Paste 2 increased from 0.560 up to 0.665 . These increases of photovoltaic factors are attributed to the improvement of adherence and better alloying of the aluminum with the silicon wafer. Compared to solar cells with Paste 2 and Paste 3, $J_{\text {sc }}$ of the solar cell with Paste 3 increased from $33.74 \mathrm{~mA} / \mathrm{cm}^{2}$ to up to $34.70 \mathrm{~mA} / \mathrm{cm}^{2}$. Average efficiencies of the 3 fabricated cells using Paste 1, Paste 2, and Paste 3 were $11.14 \%, 12.19 \%$, and $13.31 \%$, respectively. The best efficiency of $14.0 \%$ for the cells with flat surface and without ARC was achieved when using Paste 3 with $J_{\mathrm{sc}}$ of $36.0 \mathrm{~mA} / \mathrm{cm}^{2}$, open circuit voltage $\left(V_{\text {oc }}\right)$ of $539 \mathrm{mV}$, and fill factor (FF) of 0.721 . Better performance of Paste 3 could be attributed mainly to the better alloying of the paste with a uniform back surface field.

Additionally, p-type solar cells were fabricated on alkaline-textured CZ-Si wafers with spray deposited $\mathrm{TiO}_{2} \mathrm{ARC}$, which can be called "nonvacuum processed crystal-silicon 
TABLE 5: Electrical properties of fabricated cells with developed polyvinyl alcohol-based aluminum pastes (average of 3 textured, w/ARC cells).

\begin{tabular}{|c|c|c|c|c|c|}
\hline Paste & & $J_{\mathrm{sc}}\left[\mathrm{mA} / \mathrm{cm}^{2}\right]$ & $V_{\mathrm{oc}}[\mathrm{mV}]$ & $\mathrm{FF}[\%]$ & $\eta[\%]$ \\
\hline \multirow{2}{*}{ Paste 1} & Average & 35.64 & 556 & 74.3 & 14.72 \\
\hline & $( \pm)$ & 0.8 & 3.8 & 0.9 & 0.24 \\
\hline \multirow{2}{*}{ Paste 2} & Average & 37.31 & 552 & 70.7 & 14.55 \\
\hline & $( \pm)$ & 0.4 & 1.6 & 1.1 & 0.06 \\
\hline \multirow{2}{*}{ Paste 3} & Average & 37.95 & 542 & 74.2 & 15.25 \\
\hline & $( \pm)$ & 0.4 & 1.2 & 0.4 & 0.15 \\
\hline \multirow{2}{*}{ Commercial paste } & Average & 36.65 & 562 & 69.0 & 14.22 \\
\hline & $( \pm)$ & 0.9 & 5.3 & 1.5 & 0.07 \\
\hline
\end{tabular}

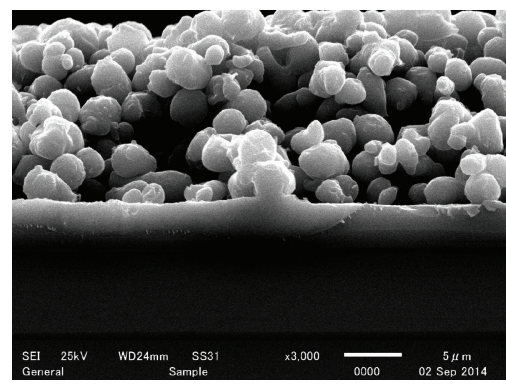

Paste 1

(a)

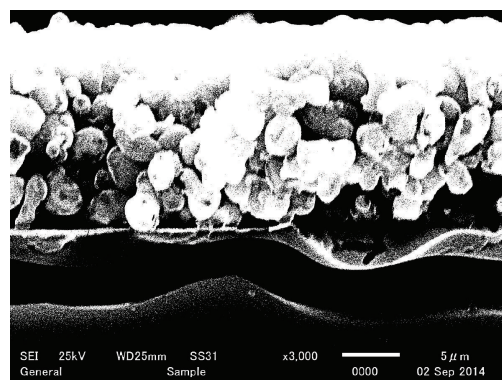

Paste 1

(d)

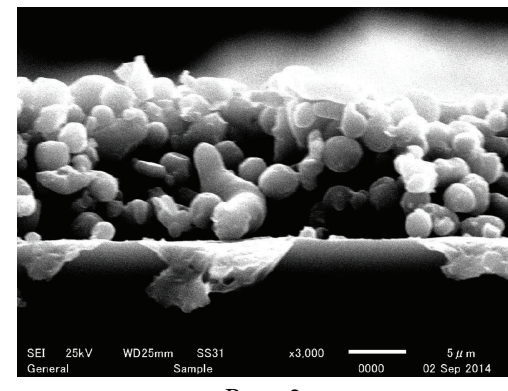

Paste 2

(b)

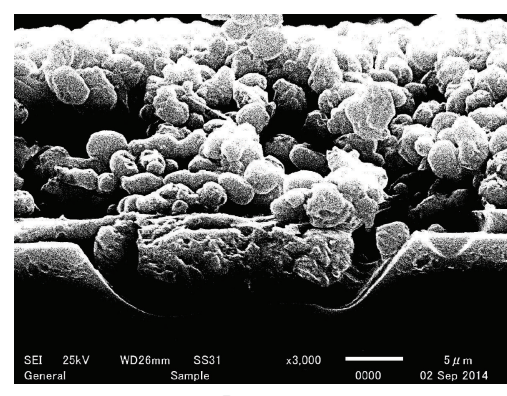

Paste 2

(e)

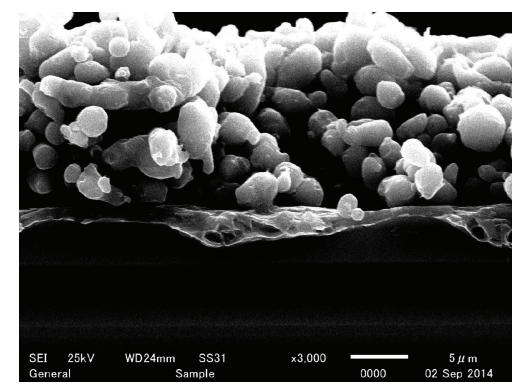

Paste 3

(c)

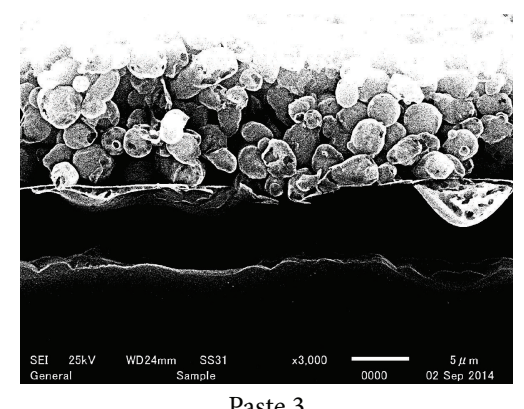

(f)

FIGURE 3: SEM images of fabricated cells using each paste before etching with acidic solution (a), (b), and (c) and after chemical etching (d), (e), and (f), for Paste 1, Paste 2, and Paste 3, respectively.

solar cells." In this case, commercially available aluminum paste was also utilized for the reference. The electrical characteristics of the solar cells with textured surface and $\mathrm{TiO}_{2}$ ARC are summarized in Table 5, and the $I-V$ curves of best cells are shown in Figure 4. Average efficiencies of the cells using Paste 1, Paste 2, and Paste 3 were $14.71 \%$, $14.55 \%$, and $15.25 \%$, respectively. The best efficiency of $15.5 \%$ was achieved when using Paste 3 with $J_{\mathrm{sc}}$ of $38.9 \mathrm{~mA} / \mathrm{cm}^{2}$, open $V_{\text {oc }}$ of $539 \mathrm{mV}$, and fill factor FF of 0.74 . Owing to the decreased optical losses, significant improvement on $J_{\text {sc }}$ and thus the FF can be seen clearly. The overall low $V_{\text {oc }}$ of the cells can be attributed to the absence of passivation layer $\left(\mathrm{SiN}_{x}\right.$ or $\left.\mathrm{Al}_{2} \mathrm{O}_{3}\right)$. Higher $V_{\text {oc }}$ is likely to be achieved with such passivation layers, and the further optimization of the pastes and firing conditions is necessary. Average efficiency of 3 solar cells with commercially available aluminum paste was
$14.26 \%$, up to $1 \%$ lower than that of the cells with developed pastes in this work. Optimizations and improvement of the paste are still in progress and better results are expected.

\section{Conclusion}

PVA-based screen-printing aluminum pastes were developed and introduced as an alternative to ethyl cellulose-based commercial aluminum pastes. Polyvinyl alcohol is a watersoluble nontoxic polymer that can be synthesized without $\mathrm{NaOH}$ saponification. According to the evaluations, developed PVA-based aluminum paste (Paste 3) prepared by two aluminum powders with particle sizes of $3.0-3.6 \mu \mathrm{m}$ and $45 \mu \mathrm{m}$, aluminum oxide $(35-50 \mu \mathrm{m})$, and acetic acid was found to be the most suitable for the silicon solar cells with better alloying of aluminum with silicon and with relatively 


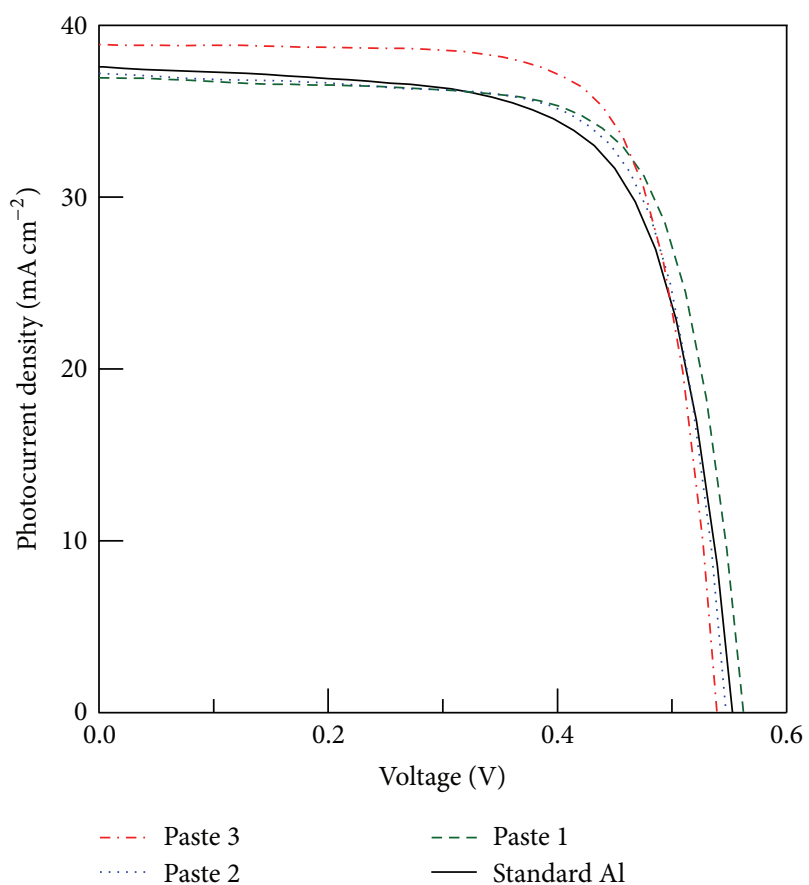

FIGURE 4: $I-V$ curve of the best cells with polyvinyl alcohol-based aluminum pastes (Paste 1, Paste 2, and Paste 3 ) compared to the best cell with commercially available aluminum paste.

uniform back surface field. Solar cells were fabricated on CZ-Si p-type wafers using PVA-based developed aluminum pastes and compared to those using a commercially available aluminum paste. Average efficiencies of 3 solar cells using Paste 1, Paste 2, and Paste 3 were $14.71 \%, 14.55 \%$, and $15.25 \%$, respectively, which were higher than the average of reference cells $(14.26 \%)$ fabricated using a commercially available aluminum paste.

\section{Conflict of Interests}

The authors declare that there is no conflict of interests regarding the publication of this paper.

\section{References}

[1] Y. Schiele, F. Book, S. Seren, G. Hahn, and B. Terheiden, "Screen-printed al-alloyed rear junction solar cell concept applied to very thin $(100 \mu \mathrm{m})$ large-area n-type Si wafers," Energy Procedia, vol. 27, pp. 460-466, 2012.

[2] M. Moors, K. Baert, T. Caremans, F. Duerinckx, A. Cacciato, and J. Szlufcik, "Industrial PERL-type solar cells exceeding 19\% with screen-printed contacts and homogeneous emitter," Solar Energy Materials and Solar Cells, vol. 106, pp. 84-88, 2012.

[3] S. Gatz, K. Bothe, J. Müller, T. Dullweber, and R. Brendel, "Analysis of local Al-doped back surface fields for high efficiency screen-printed solar cells," Energy Procedia, vol. 8, pp. 318-323, 2011.

[4] H. M. Lee and Y.-J. Kim, "Preparation of size-controlled fine Al particles for application to rear electrode of Si solar cells," Solar
Energy Materials and Solar Cells, vol. 95, no. 12, pp. 3352-3358, 2011.

[5] D. Kim, J. Kim, J. Lee, and H. Kim, "Characteristics of Si solar cells with the addition of frits and additives to Al pastes," Japanese Journal of Applied Physics, vol. 50, no. 11, Article ID 11RF01, 2011.

[6] Reported in a news paper, Yomiuri News, Japan, pp. 1-2, 26th July 2012.

[7] S. Ito, P. Chen, P. Comte et al., "Fabrication of screen-printing pastes from $\mathrm{TiO}_{2}$ powders for dye-sensitised solar cells," Progress in Photovoltaics: Research and Applications, vol. 15, no. 7, pp. 603-612, 2007.

[8] W. Kern and D. A. Puotinen, "Cleaning solutions based on hydrogen peroxide for use in silicon semiconductor technology," RCA Review, vol. 31, pp. 187-206, 1970.

[9] K. Reinhardt and W. Kern, Eds., Handbook of Silicon Wafer Cleaning Technology, William Andrew, 2nd edition, 2008.

[10] P. Qin, S. Tanaka, S. Ito et al., "Inorganic hole conductor-based lead halide perovskite solar cells with $12.4 \%$ conversion efficiency," Nature Communications, vol. 5, article 3834, 2014. 

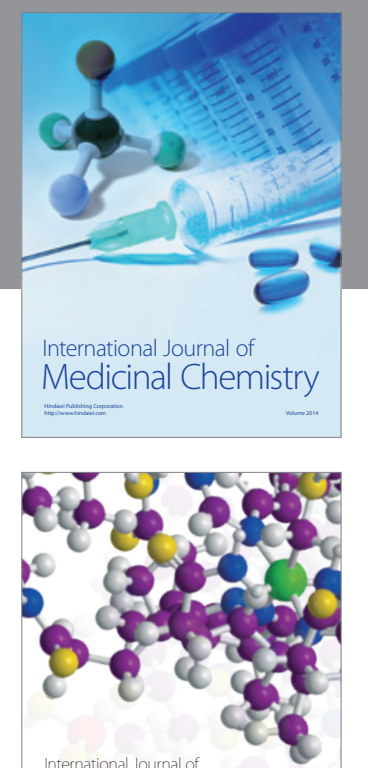

\section{Carbohydrate} Chemistry

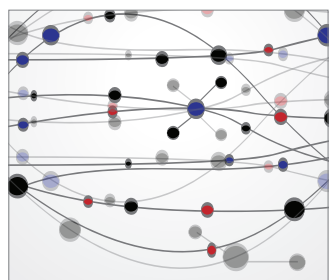

The Scientific World Journal
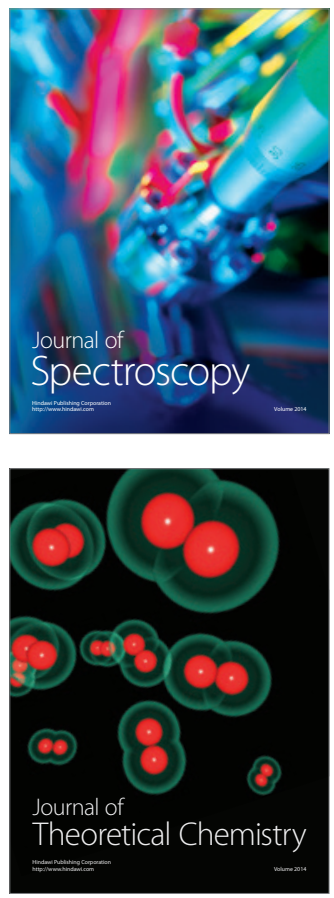
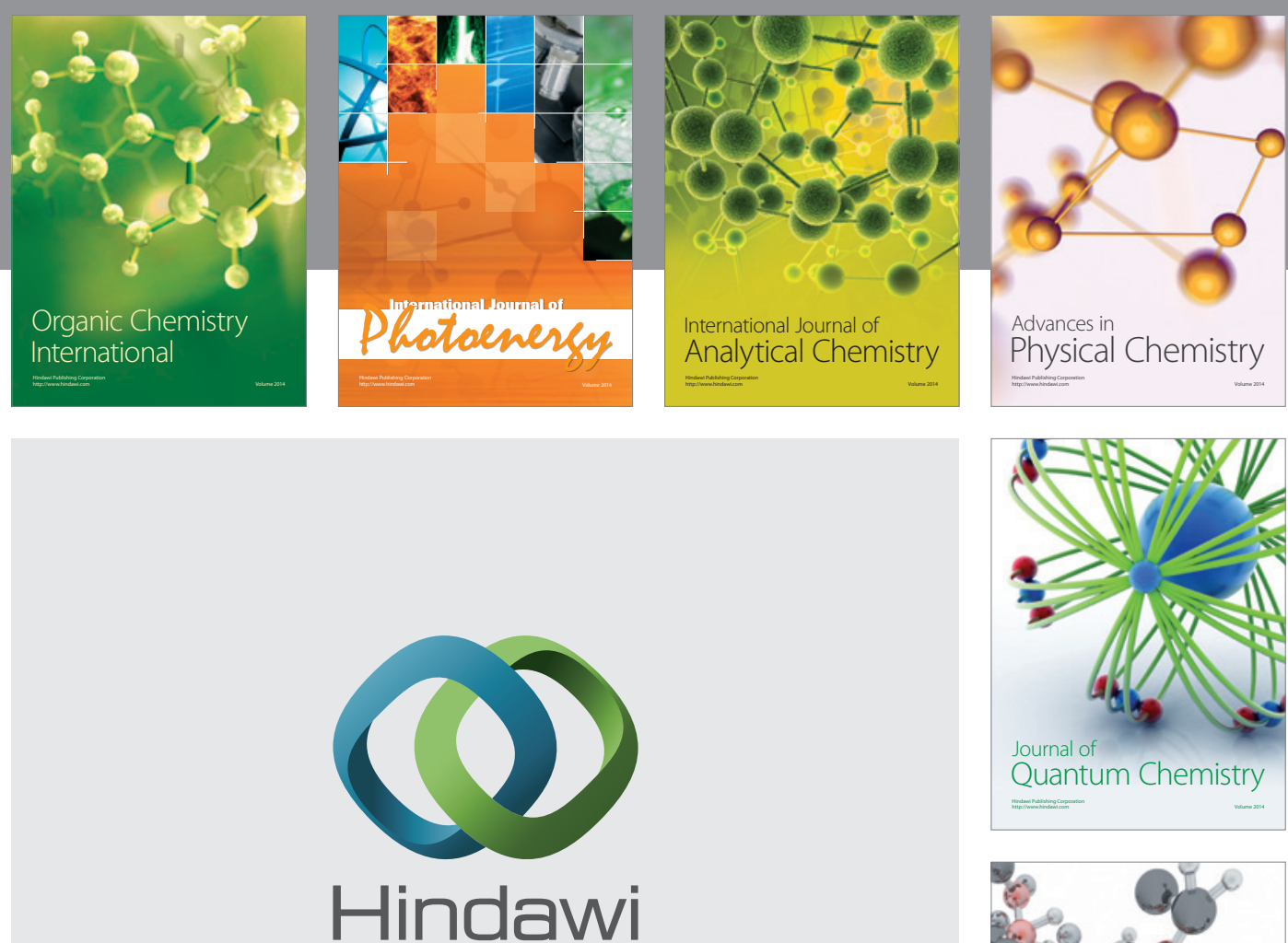

Submit your manuscripts at

http://www.hindawi.com

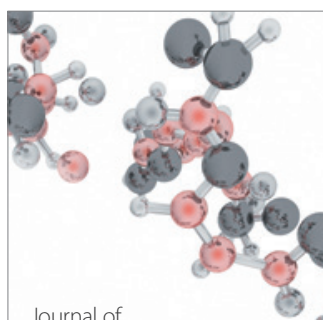

Analytical Methods

in Chemistry

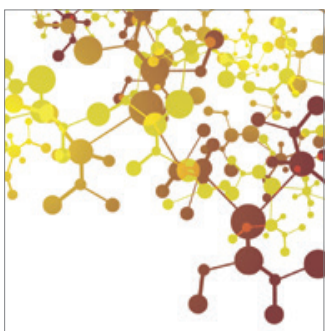

Journal of

Applied Chemistry

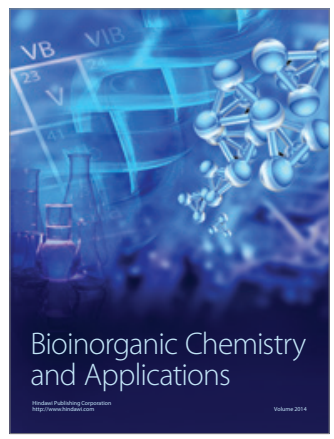

Inorganic Chemistry
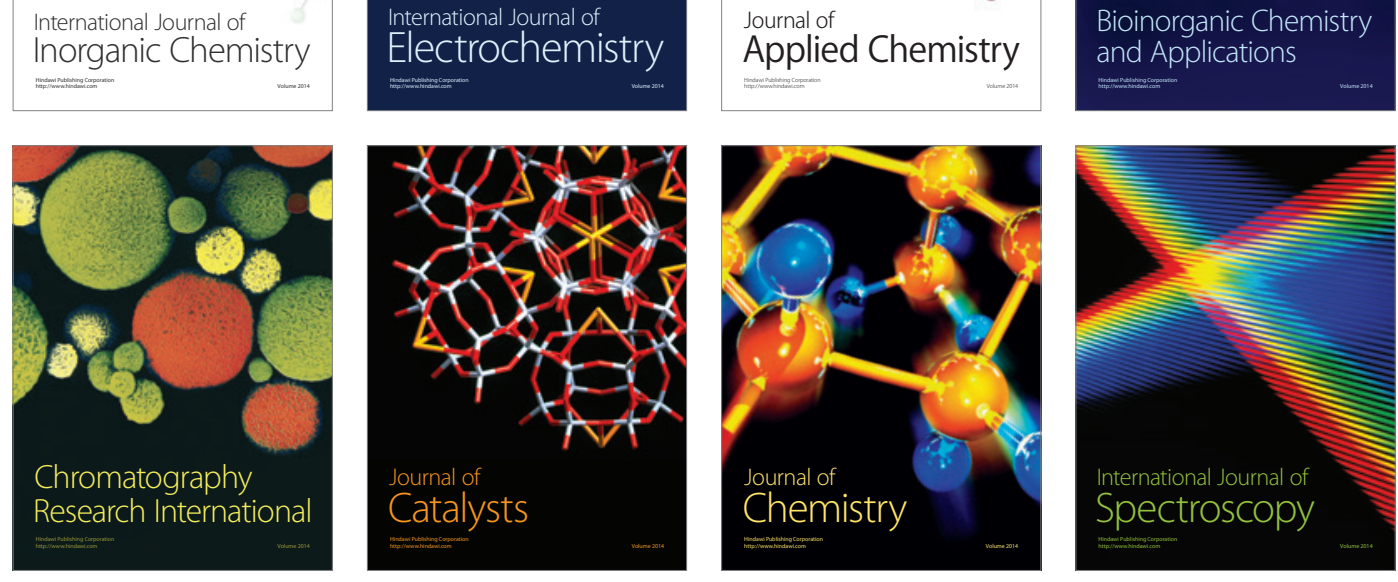